\title{
A method for cleaning tanks from oil product residues based on biotechnology
}

\author{
Obid Hamroyev ${ }^{1 *}$, Nargiza Ravshanova ${ }^{1}$, Vasik Jovliyev ${ }^{1}$ and Suxrob Komiljonov ${ }^{2}$ \\ ${ }^{1}$ Karshi Engineering Economic Institute, Karshi, Uzbekistan \\ ${ }^{2}$ Tashkent State Transport University, Tashkent, Uzbekistan
}

\begin{abstract}
The known methods of cleaning tanks from the remnants of petroleum products using existing means are quite time-consuming, energy-intensive, and insufficiently advanced. In addition, waste cleaning solutions are poorly regenerated and slowly oxidized in the biosphere, and their removal to landfills (or discharge into reservoirs) causes great harm to the environment. Therefore, the search for new methods of cleaning is a very urgent task. This work aims to develop a method for cleaning tanks from the residues of petroleum products based on biotechnology. This article proposes a technological scheme of an experimental installation that simulates a tank for storing petroleum products in agricultural conditions. Studies on the oxidation of petroleum product residues by selected active cultures of microbial strains have been carried out. The modes of biological cleaning of the internal surfaces of tanks for the storage of petroleum products, from their residues, are determined. Strains of oiloxidizing microorganisms were used as biologics). The biomass of the studied microorganisms was obtained under laboratory conditions by deep cultivation in flasks on a mineral medium. The proposed method of tank cleaning is an environmentally friendly process, during which microorganisms decompose oil pollution at relatively low temperatures $\left(20-40^{\circ} \mathrm{C}\right)$ and use hydrocarbons as a source for their growth. As a result of this process, many tons of oil deposits are converted into microbial cells, which in turn become a source of food for other organisms and the plant world.
\end{abstract}

\section{Introduction}

In Uzbekistan, large-scale measures are being taken to reduce the cost of fuel and lubricants, save them when performing agricultural work. Research works are being carried out to create energy-saving machines for tillage [1-21], sowing [22-23], harvesting [24], and processing [25] crops. The main goal is to reduce the cost of fuel and lubricants for agricultural work. The productivity of agricultural products mainly depends on the timely provision of fuel and lubricants for energy resources [28-41].

During long-term storage and transportation of petroleum products in the tanks, changes in the component composition occur, which leads to the accumulation of a large number of oil residues, which negatively affect the quality of petroleum products re-filled in these

\footnotetext{
*Corresponding author: khamroev.obid@mail.ru
} 
tanks. Contaminated fuel entering the fuel tanks of engines can cause serious damage, which leads to overspending of fuel by engines and, in general, to a decrease in the reliability and durability of machine parts and components. The quality of petroleum products is ensured during their storage and transportation using clean containers, which is possible only in the case of periodic cleaning of their residues of petroleum products and contaminants.

Tank cleaning is a very time-consuming process. The existing tank cleaning methods at the oil complexes of agricultural enterprises can be divided into two types: manual and mechanized. Manual cleaning method, currently almost not used.

The mechanized method of cleaning tanks from the residues of petroleum products at oil complexes of agricultural enterprises is carried out with the help of special installations for cleaning tanks developed in Russia. At the same time, an aqueous solution of preparations such as MS, ML," Labomid," and others, heated to $80-90^{\circ} \mathrm{C}$, is used as a washing liquid.

This method significantly reduces the cleaning time, reduces the amount of manual labor and the cost of the process, but it has significant drawbacks.

The disadvantages of the mechanized method are the high energy consumption for heating cold water to a temperature of $80-90^{\circ} \mathrm{C}$ and the need for manual labor when unloading "dead" sediments from the tank. In addition, its significant disadvantage is the need to pump out the spent cleaning solution containing the remains of contaminated petroleum products in the tanks of treatment plants. Sometimes the waste solutions are taken to a landfill or drained into reservoirs, which causes great harm to the environment.

The known methods of cleaning tanks from the remnants of petroleum products using existing means are quite time-consuming, energy-intensive, and insufficiently advanced. In addition, waste cleaning solutions are poorly regenerated and slowly oxidized in the biosphere, and their removal to landfills (or discharge into reservoirs) causes great harm to the environment. Therefore, the search for new methods of cleaning is a very urgent task.

This work aims to develop a method for cleaning tanks from the residues of petroleum products based on biotechnology. The article sets the following tasks:

- to justify the possibility of biological cleaning of objects from oil pollution;

- develop a method for assessing the ability of microorganisms to disperse petroleum products;

- to determine the ability of microorganisms to absorb the remnants of petroleum products in the experimental facility;

- to develop a technology for the biological purification of tanks from the residues of petroleum products.

\section{Methods}

The objects of research were samples contaminated with residues of petroleum products, as well as tanks for their storage. As preparations of microbial biomass, strains of oiloxidizing microorganisms from the Sintez Belok Research Institute (Russia) collection were used. The biomass of the studied microorganisms was obtained in the laboratory by deep cultivation of them in flasks on mineral medium № 9. In the medium for growing yeast, the $\mathrm{pH}$ was established-5.0-5.5; for bacteria, 6.8-7.0. The amount of seed material 0.1 units of optical density about the volume of the nutrient medium. Cultivation mode: the temperature is optimal for the growth of each strain of the microorganism; the duration is 48 hours. An experimental setup has been developed for laboratory studies of the new cleaning method. The main part of the installation is the tank, which is a horizontal cylinder with a capacity of 10 liters made of organic glass. The following components are installed in the tank: bubbler (air supply system); heat exchanger, which is connected by silicone 
hoses with a thermostat; electrodes for measuring the $\mathrm{pH}$ of the medium; resistance thermometer; sampling valve. The research was carried out using modern equipment and devices, the use of modern research methods, the processing of the obtained data by methods of mathematical statistics and trial tests.

The hydrocarbon composition of oil-derived pollutants is characterized. The selection of microorganisms that utilize the hydrocarbons of oil pollution was carried out. According to their ability to utilize various fractions of petroleum hydrocarbons, the qualitative and quantitative characteristics of the selected microorganisms are given. The biological method of tank cleaning from oil product residues is experimentally proved.

\section{Results and Discussion}

The research results made it possible to develop a technology for the biological cleaning of tanks from the remnants of petroleum products. The technology includes the following operations:

- obtaining the necessary amount of biomass (seed material) of microorganisms for the process;

- implementation of the process of biological cleaning of the tank;

- separation of the biomass from the culture fluid.

To obtain (prepare) the required amount of biomass, a biological laboratory is organized at the district sanitary and epidemiological station. Biological cleaning of tanks is carried out according to the scheme shown in Figure 1.

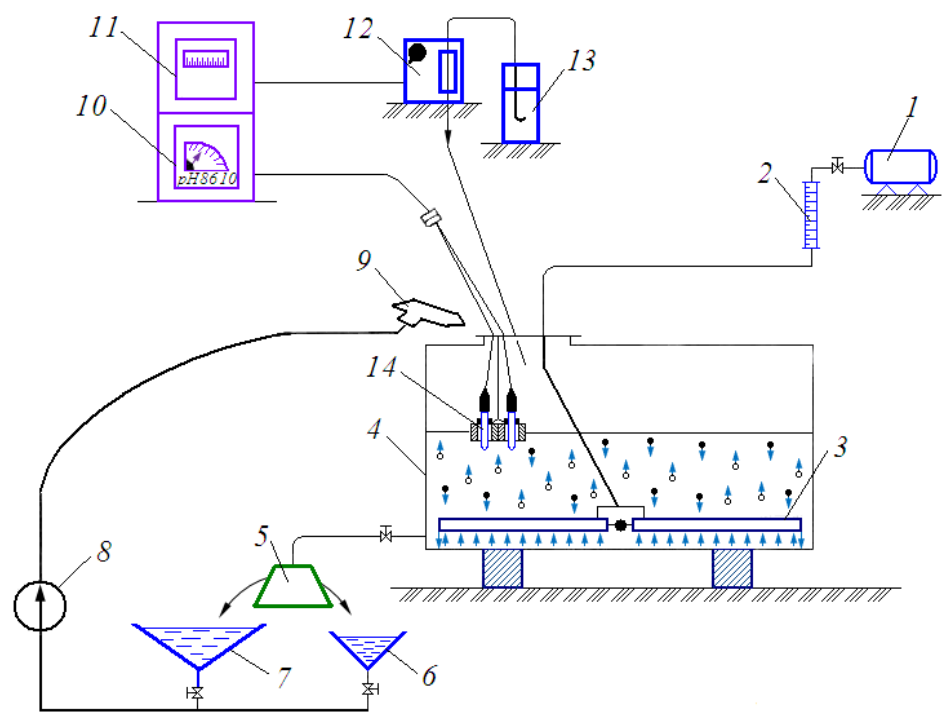

Fig. 1. Technological scheme of biological cleaning of tanks from oil product residues: 1 is compressor; 2 is rotameter; 3 is bubbler; 4 is tank; 5 is separator; 6 is container for biomass; 7 is container for culture liquid; 8 is pump; 9 is hydromonitor; 10 is $\mathrm{pH}$ meter; 11 is register; 12 is pumpdispenser; 13 is vessel for titrating liquid; 14 are electrodes for measuring the $\mathrm{pH}$ of the medium.

The tank 4 with the remnants of petroleum products is filled with seed material (the biomass of microorganisms in the required amount), where the bubbler 3 is released, and the compressor 1 is turned on. In this case, the air passing through the rotameter 2 rushes into the cavity of the bubbler 3 , which provides intensive aeration in the air. This ensures the growth of microorganisms, with their uniform distribution over the entire volume of the 
tank. Accordingly, the cleaning process is accelerated. Cleaning mode: the amount of seed material should ensure its optical density in the medium is not less than 0.5 units when measured in a cuvette of $5 \mathrm{~mm}$; the $\mathrm{pH}$ of the medium is 5.0-5.5 for yeast; 6.8-7.0 for bacteria; medium temperature $26-40^{\circ} \mathrm{C}$, depending on the type of microorganism. Air consumption $3 \mathrm{l} / \mathrm{lmin}$ ( 3 liters per liter of pollution per minute). A rotameter regulates the air flow rate. The $\mathrm{pH}$ environment is controlled by a $\mathrm{pH}$ meter and is maintained automatically.

Since the tanks are cleaned in the summer, the ambient temperature is sufficient to carry out the process. If necessary, an electric air heater can be installed on the air supply line, with the help of which it is easy to maintain the temperature of the bubbled liquid in the process stages of $26-40^{\circ} \mathrm{C}$.

At the end of the biological treatment cycle, a separator is activated in the oil pollution tank, where cells are isolated from the culture liquid. The cells of microorganisms enter the container 6 , and the clarified culture liquid enters the container 7 . Then the purified culture liquid is fed through the pump 8 and the hydraulic monitor 9 to the tank 4 for jet removal of the cells remaining on the tank walls and refuel the next tank with oil pollution. Some of the microbial cells extracted at the separation stage can be reused, and some can be disposed of (for example, for resuscitation of the soil with contaminated oil products).

The process of extracting cells from the solution in the separation channel occurs in the field of action of centrifugal forces. (Fig.2) The speed of rotation of the separator required for the deposition of suspended cells can be determined from the Stokes equation:

$$
n=\frac{30 d^{2}\left(\gamma_{k}-\gamma_{r}\right)}{18 \pi \mu R}\left(\mathrm{~min}^{-1}\right) .
$$

where $\mu$ is the coefficient of dynamic viscosity $\mathrm{m}^{-1} \cdot \mathrm{kg} \cdot \mathrm{sec}^{2} ; d$ is the average diameter of the cell, $\mathrm{m} ; R$ is the radius of the separating channel, $\mathrm{m} ; \gamma_{k}, \gamma_{r}$ are respectively, the density of cells (biomass) and the working solution (water), $\mathrm{g} / \mathrm{m}^{3}$.

At a certain frequency $\mathrm{n}$ of rotation and the radius $R$ of the separating channel, it is possible to ensure the optimal mode of extraction of the smallest cells in size. This effect is used to separate the spent cells.

If we take into account that $d=10$ microns, $\gamma_{k}=1.1-1.2 \mathrm{~g} / \mathrm{cm}^{3}, \gamma_{p}=1 \mathrm{~g} / \mathrm{cm}^{3}$, then at $n=(4-) 10^{3} \mathrm{~min}^{-1}$, a highly effective "pop-up" of spent cells is achieved.

Due to the mechanization of the process of extracting biologically active cells from the waste solution and reusing the clarified solution, it is possible to switch to closed biotechnological cleaning of tanks from oil pollution in the agro-industrial complex.

Due to the mechanization of the process of extracting biologically active cells from the waste solution and reusing the clarified solution, it is possible to switch to closed biotechnological cleaning of tanks from oil pollution in the agro-industrial complex. 


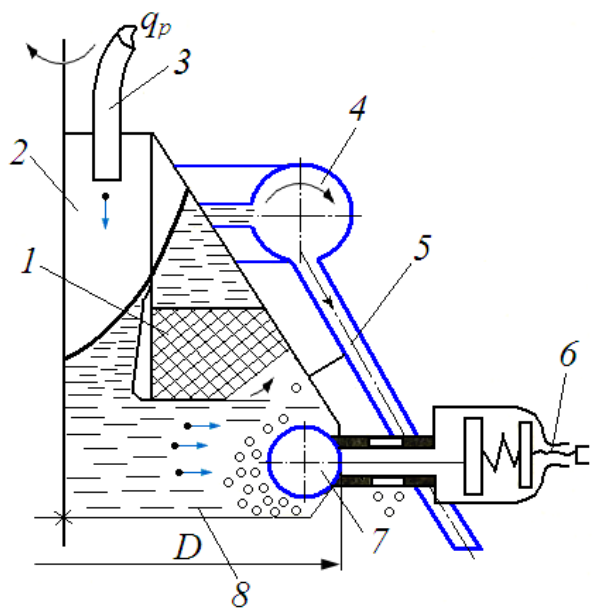

Fig. 2. Separator operation diagram: 1 is filter element; 2 is housing; 3 is supply tube; 4 is torusshaped collector: 5 is accelerator tube; 6 is adjustment element; 7 is metering valve; 8 is separating channel

\section{Conclusions}

Thus, the biotechnological (innovative) method of tank cleaning is an environmentally friendly process in which microorganisms decompose oil pollution at relatively low temperatures and use hydrocarbons as a source for their growth. As a result of this process, many tons of oil deposits are converted into microbial cells, which in turn become a source of food for other organisms and the plant world.

\section{References}

1. Mamatov, F.M., Eshdavlatov, E., Suyunov, A. The Shape of the Mixing Chamber of the Continuous Mixer // Jour of Adv Research in Dynamical \& Control Systems, Vol. 12, 07-Special Issue, (2020). DOI: 10.5373/JARDCS/V12SP7/20202318 ISSN 1943$023 \mathrm{X}$.

2. Mamatov, F., Ergashev, I., Ochilov, S., Pardaev, X. Traction Resistance of Soil Submersibility Type "Paraplau" // Jour of Adv Research in Dynamical \& Control Systems, Vol.12, 07-Special Issue, (2020). DOI: 10.5373/JARDCS/V12SP7/20202336 ISSN1943-023X.

3. Aldoshin, N., Mamatov, F., Ismailov, I., Ergashov, G. Development of combined tillage tool for melon cultivation // 19th international scientific conference engineering for rural development Proceedings, Jelgava, 20. (2020). Volume 19. ISSN 1691-5976. DOI:10.22616/ERDev.2020.19.TF175.

4. Umurzakov, U., Mirzaev, B., Mamatov, F., Ravshanov, H., Kurbonov, S. A rationale of broach-plow's parameters of the ridge-stepped ploughing of slopes // XII International Scientific Conference on Agricultural Machinery Industry IOP Conf. Series: Earth and Environmental Science 403(2019) 012163 IOP Publishing doi:10.1088/1755-1315/403/1/012163.

5. Mirzaev, B., Mamatov, F., Chuyanov, D., Ravshanov, X., Shodmonov, G., Tavashov, $\mathrm{R}$ and Fayzullayev, $\mathrm{X}$. Combined machine for preparing soil for cropping of melons and gourds // XII International Scientific Conference on Agricultural Machinery Industry. doi.org/10.1088/1755-1315/403/1/012158.

6. Mirzaev, B., Mamatov, F., Ergashev, I., Ravshanov, H., Mirzaxodjaev, Sh., Kurbanov, 
Sh., Kodirov, U and Ergashev, G. Effect of fragmentation and pacing at spot ploughing on dry soils // E3S Web of Conferences 97. doi.org/10.1051/e3sconf/201913501065.

7. Mamatov, F., Mirzaev, B., Batirov, Z., Toshtemirov, S., Tursunov, O., Bobojonov, L. Justification of machine parameters for ridge forming with simultaneous application of fertilizers // CONMECHYDRO - (2020) IOP Conf. Series: Materials Science and Engineering 883(2020) 012165 IOP Publishing. doi:10.1088/1757899X/883/1/012165.

8. Mirzaev, B., Mamatov, F., Avazov, I., Mardonov, S. Technologies and technical means for anti-erosion differentiated soil treatment system // E3S Web of Conferences. doi.org/10.1051/e3sconf/20199705036.

9. Mirzaev, B., Mamatov, F., Aldoshin, N and Amonov, M. Anti-erosion two-stage tillage by ripper// Proceeding of 7th International Conference on Trends in Agricultural Engineering 17th-20th. Czech Republic. - pp.391-396. September (2019).

10. Mirzaev, B., Mamatov, F., Ergashev, I., Islomov, Yo., Toshtemirov, B., Tursunov O. Restoring degraded rangelands in Uzbekistan// Procedia Environmental Science, № 6. - pp 395-404. (2019).

11. Uzakov, Z.U., Mamatov, F.M., Begulov, O. Implementation of object-oriented Programming technology in the one-dimensional oil displacement problem // International Conference on information Science and Communications Technologies: ICISCT 2019/0012008. Tashkent, Uzbekistan. INSPEC Accession Number: 19412491. DOI: 10.1109/ICISCT47635.2019.9012008.

12. Mamatov, F., Mirzaev, B., Tursunov, O. A Justification of Broach-Plow's Parameters of the Ridge-Stepped Ploughing // E3S Web of Conferences 97, 05035 (2019). doi.org/10.1051/e3sconf/20199705035.

13. Ahmedov, B.J., Mirzaev, B.S.,Mamatov, F.M., Khodzhaev, D.A., Julliev, M.K. Integrating of gis and gps for ionospheric perturbations in d- And f-layers using vlf receiver // InterCarto, InterGIS 26, - c. 547-560. DOI: 10.35595/2414-9179-(2020)-126-547-560.

14. Mamatov, F., Mirzaev, B., Tursunov, O., Ochilov, S and Chorieva, D. Relief, physicomechanical and technological properties of soil in the cotton growing area // ICECAE (2020). IOP Conf. Series: Earth and Environmental Science 614(2020) 012169. IOP Publishing. doi:10.1088/1755-1315/614/1/012169.

15. Shamsutdinov, Z., Ubaydullaev, Sh., Shamsutdinov, N., Mirzaev, B., Mamatov, F., and Chorshabiyev, N. The concept of the phytogenic field: theory, research experience and practical significance // ICECAE (2020). IOP Conf. Series: Earth and Environmental Science 614(2020) 012164. IOP Publishing. doi:10.1088/1755-1315/614/1/012164.

16. Umurzakov, U., Mamatov, F., Aldoshin, N., and Mirzaev, B. Exploration of tillage technologies in the Republic of Uzbekistan // ICECAE (2020) IOP Conf. Series: Earth and Environmental Science 614(2020) 012168. IOP Publishing. doi:10.1088/17551315/614/1/012168.

17. Mamatov, F., Aldoshin, N., Mirzaev, B., Ravshanov, H., Kurbanov, Sh and Rashidov, N. Development of a frontal plow for smooth, furless plowing with cutoffs // IPICSE (2020). IOP Conf. Series: Materials Science and Engineering 1030 (2021) 012135 IOP Publishing. doi:10.1088/1757-899X/1030/1/012135.

18. Mamatov, F., Mirzaev, B., Mirzahodzhaev, Sh., Uzakov, Z and Choriyeva, D. Development of a front plow with active and passive working bodies // IPICSE (2020). IOP Conf. Series: Materials Science and Engineering 1030 (2021) 012164. IOP Publishing. doi:10.1088/1757-899X/1030/1/012164.

19. Mamatov, F., Ergashev, I., Mirzaev, B., Pardaev, X, Chorieva, D. Research of the Penetration Process of the Frontal Plow // 2nd Bukittinggi International Conference on Education (BICED) (2020). Journal of Physics: Conference Series 1779 (2021) 
012002. IOP Publishing. doi:10.1088/1742-6596/1779/1/012002.

20. Kodirov, U., Aldoshin, N., Ubaydullayev, Sh., Sharipov, E., Muqimov, Z and Tulaganov, B. The soil preparation machine for seeding potatoes on comb // CONMECHYDRO - (2020). IOP Conf. Series: Materials Science and Engineering 883(2020) 012143 IOP Publishing doi:10.1088/1757-899X/883/1/012143.

21. Ravshanov, Kh., Fayzullaev, Kh., Ismoilov, I., Irgashev, D., Mamatov, S. The machine for the preparation of the soil in sowing of plow crops under film // CONMECHYDRO - (2020) IOP Conf. Series: Materials Science and Engineering 883(2020) 012138 IOP Publishing doi:10.1088/1757-899X/883/1/012138.

22. Mamatov, F., Mirzaev, B., Berdimuratov, P., Turkmenov, Kh., Muratov, L., Eshchanova, G. The stability stroke of cotton seeder moulder // CONMECHYDRO (2020). IOP Conf. Series: Materials Science and Engineering 883 (2020) 012145 IOP Publishing. doi:10.1088/1757-899X/883/1/012145.

23. Mamatov, F., Mirzaev, B., Shoumarova, M., Berdimuratov, P., Khodzhaev, D. Comb former parameters for a cotton seeder// International Journal of Engineering and Advanced Technology (IJEAT) Volume-9 Issue1 October/ DOI: 10.35940/ijeat.A2932.109119.

24. Aldoshin, N., Didmanidze, O., Mirzayev, B., Mamatov, F. Harvesting of mixed crops by axial rotary combines // Proceeding of $7^{\text {th }}$ International Conference on Trends in Agricultural Engineering (2019). $17^{\text {th }}-20^{\text {th }}$ Prague, Czech Republic. - pp.20-26. September (2019).

25. Mamato, F.M., Eshdavlatov, E., Suyuno, A. Continuous Feed Mixer Performance //Journal of Advanced Research in Dynamical and Control Systems (JARDCS). Volume-12, 07-Spesia1 Issue, (2020). DOI: 10.5373/JARDCS/V12SP7/20202343. ISSN 1943-023X.

26. Ravshanov, H, Babajanov, L, Kuziev, Sh, Rashidov, N, Kurbanov, Sh. Plough hitch parameters for smooth tails// CONMECHYDRO - (2020) IOP Conf. Series: Materials Science and Engineering 883(2020) 012139 IOP Publishing doi:10.1088/1757899X/883/1/012139.

27. Chuyanov, D., Shodmonov, G.,Avazov, I., Rashidov, N, Ochilov, S. Soil preparation machine parameters for the cultivation of cucurbitaceous crops // CONMECHYDRO - (2020) IOP Conf. Series: Materials Science and Engineering 883(2020) 012139 IOP Publishing doi:10.1088/1757-899X/883/1/012122.

28. Kislukhina O. V., Khamroev O. Zh, Morshakova G. N., Bitteeva M. B. Determination of the ability of microorganisms to disperse petroleum products. Ecology No. 3.(1993).

29. Khamroev O. Zh. Investigation of the ability of active cultures of microorganisms to assimilate pollution of oil origin / / Universum: Technical sciences: electron. scientific. journal. (2020). No. 5 (74). URL: http://7universum.com/ru/tech/archive/item/9348.

30. Telnov N. F. Technology of ochiski of agricultural machinery. M.: Kolos, (1983).

31. Churbanova I. N. Microbiology. - M.: Higher School, - p. 239. (1987).

32. Litvinenko S. N. Protection of petroleum products from the action of microorganisms. Moscow: 144 p. (1977).

33. Kislukhina O. V., Kalunyants K. A., Alenova D. Zh. Enzymatic lysis of microorganisms. Alma-Ata: p. 200. Rauan, (1990).

34. Khamroev O. Zh. Investigation of the ability of microorganisms to disperse petroleum products. // Science, Technology and Education . No. 4 (68) p. 20. (2020).

35. Khamroev O. Zh. Accelerated method for determining the ability of biological products for biological cleaning of waste cleaning solutions from petroleum products. Bulletin of Science and Education. No. 3 (106). p. 25. (2021).

36. Khamroev O. Zh. A method for solving an environmental problem in the process of cleaning machines at motor transport enterprises. Science, technology, and education. 
№ 2. (2021).

37. Batirov Z., Toirov I., Boymuratov F., Sharipov Sh. Layered application of mineral fertilizers with the coulter ripper of a combined unit//IOP Conf. Series: Materials Science and Engineering 1030 (2021).doi: 10.1088/1757-899X/1030/1/012168.

38. Mamatov, F., Mirzaev, B., Batirov, Z., Toshtemirov, S., Tursunov, O., Bobojonov, L. Justification of machine parameters for ridge forming with simultaneous application of fertilizers // CONMECHYDRO - (2020) IOP Conf. Series: Materials Science and Engineering 883(2020) 012165 IOP Publishing. doi:10.1088/1757$899 X / 883 / 1 / 012165$.

39. Marupov, I, Imomov, Sh, Ermatova, D, Majitov,J, Kholikova, N, Tagaev, V, and Nuritov, I. Research of vertical forces for acting tractor unit // ICECAE (2020). IOP Conf. Series: Earth and Environmental Science 614(2020) 012153. IOP Publishing. doi:10.1088/1755-1315/614/1/012153.

40. Alimova, Z, Kholikova, $\mathrm{N}$ and Kholova, S. Improvement of properties of oils used in hydraulic systems of road-construction equipment // CONMECHYDRO - (2020). IOP Conf. Series: Materials Science and Engineering 883(2020) 012167. IOP Publishing. doi:10.1088/1757-899X/883/1/012167.

41. Imomov, Sh, Kholikova, N, Alimova, Z, Nuritov, I, Temirkulova, N. Oil Purification Devices Used in Internal Combustion Engines // International Journal of Innovative Technology and Exploring Engineering (IJITEE). ISSN: 2278-3075. Retrieval Number: A9141119119/2019@BEIESP. DOI: 10.35940/ijitee.A9141.119119. 